\title{
観測記録に基づく実大鉄骨架構の物理パラメタの同定に関する研究 A STUDY ON IDENTIFICATION OF THE PHYSICAL PARAMETERS OF A FULL-SCALE STEEL STRUCTURE BASED ON OBSERVED RECORDS
}

\author{
畠山直已*, 松島信 一**, 川瀬 博*** \\ Naoki HATAKEYAMA, Shinichi MATSUSHIMA and Hiroshi KAWASE
}

\begin{abstract}
In order to predict seismic damage of a building, we must identify its major physical parameters, that is, shear and bending stiffness and mass. However, it is difficult to directly estimate these physical parameters. In this study, we try to identify the physical parameters of a full-scale five-storied structure based on the observed microtremor records. First, we estimate resonant frequencies by using Fourier spectral ratios of each floor response with respect to the ground. We then observe the changes of these resonant frequencies due to loading of an added weight with known amount. Finally, using an equivalent lumped mass flexural-shear model, we identify its physical parameters through the Hybrid Heuristic Search method.
\end{abstract}

Keywords : Microtremor measurement, Resonant frequency, Added mass, Physical parameter, equivalent flexural-shear model 常時微動観測, 共振振動数, 付加質量, 物理パラメタ, 等価曲げせん断型モデル

\section{1. はじめに}

東海・東南海・南海地震を控えた今日では、既存の構造物の特性 を知り、地震時の応答を正確に予測することはますます重要となっ ている。さらに、地震を受けたことによる多層構造物の損傷を検知 することは、地震後の耐震診断、補強等において必要不可欠である。 地震の応答予測のためには、事前に地震時の応答や常時微動等の観 測を行い、質量・剛性といった構造物の物理パラメタを同定してお くことが必須である。また、このシステム同定によって、損傷箇所 の検出を行う構造ヘルスモニタリング技術の向上が期待できる。

本研究の同定では、質量と剛性を同程度の精度で同定することを 目標としている。これは比較する時間間隔が長い場合には使用状況 の変化や補強・補修等による質量変化も大きいと考えられること、 地震応答解析を行って被害を予測するには剛性のみならず質量の影 響も大きく現れることを考慮しているためである。もちろん地震前 後の相対的な剛性変化を把握するための同定などではその間の質量 変化は無視できると考えられるが、その場合でも得られる剛性変化 は仮定した質量分布の影響を受ける。なお減衰定数に関しては、一 般構造物でもS造の場合1 3\%程度とされており、今回の対象構造物 は壁もブレースも非構造部材も無く、柱・梁・床スラブのみで構成 されているために、減衰定数が小さいと考えられることから、今回 は同定対象とはしていない。

集中質点系の物理パラメタの中でもせん断型モデルの層剛性を同 定する既往研究は数多く存在し、例えば中村ら ${ }^{1)}$ は、常時微動計測 に基づき、層剛性を同定しているが、得られた剛性は仮定した質量
に起因する誤差を含んでいる。また、池田2) は、モード情報を拘束 条件として考慮して、重多付き最小自乗法でパラメタ推定を行って いるが、重みの設定が難しいという問題がある。さらに、前田ら3) は、限定された地震動に対しARXモデルを用いることにより伝達関 数から物理パラメタを表現寸る手法を提案している。同様に質量を 既知としている文献として、吉元ら ${ }^{4)}$ は、構造ヘルスモニタリング 用に信頼性の高い帯域情報を用いたモード情報に基づいた方法を提 案し、また濱本らは、下部加振と上部加振を併用し低次と高次のモ ード特性を励起させる方法 5 )、複数モードの固有振動数変化を用い る方法6) 、逐次最小二乗法により地震時の損傷進行を追跡する方法 7)、フレームモデルを曲げせん断モデルに集約し部材レベルの損傷 を検出する方法8)などを報告している。一方、文献6) と同様の大型 鉄骨フレーム模型を用いた実験でSaitoら ${ }^{9)}$ は、せん断型モデルの適 用に限界があることを指摘し、フルマトリックスの要素を直接同定 する方法を提案、損傷箇所が検出できることを報告している。

これに対して、池田ら 10) は、刺激関数を用いて、様々な初期条件、 制約条件を課した線形計画法により、各層の質量の同定を行ってい る。その結果、初期条件、制約条件の設定によって同定結果にばら つきがあることを報告しているが、これは刺激関数に与える質量の 影響が顕著でないことを反映した当然の結果であろう。また、質量 を含めた物理パラメタを直接推定する手法として、古川ら 11) は、可 変振り子センサを用いた手法を提案し、既存の木造住宅の動特性を 同定している。このセンサは質量・剛性・粘性減衰定数が既知で、 かつ剛性を変化させることができ、剛性を変更するたびに加振実験
$*$ 京都大学大学院工学研究科 修士課程 $\cdot$ 学士 (工学)

** 京都大学防荻研究所 准教授・博士 (工学 $)$

*** 京都大学防災研究所 教授. 博士 (工学)
Graduate Student, Graduate School of Engineering, Kyoto University, M. Eng. Assoc. Prof., Disaster Prevention Research Institute, Kyoto University, Dr. Eng. Prof., Disaster Prevention Research Institute, Kyoto University, Dr. Eng. 
を行うことでパラメタ推定が可能である。しかし、剛性マトリクス 等が大きくなり、計算負荷が大きくなるという難点も存在する。

そこで本研究では、構造物の各階の中央に地震計を設置して連続 常時微動観測を行い、さらに質量が既知の付加質量を各階に順次載 荷する度に連続常時微動観測を行うことで、各次共振振動数の変動 を計測してそれを対象に構造物のパラメタを同定する。以前、森ら 12) は、最上階に付加質量を載荷することによって、各層の質量・剛 性の同定を試みているが、1次共振振動数のみを利用しており質 量・剛性を独立に同定できていない。また、川瀬ら 13) は、建設途中 の免震建物における質量变化から振動数变化を検知し、剛性を同定 しているが、既存の一般的構造物に対しては現実的ではない。

以下本研究では、簡便なモデルの適用性を検討するため、まず対 象構造物をせん断型モデルにモデル化し、観測記録の1次、2次共振 振動数の変化を再現できるように各層の質量・せん断剛性をグリッ ドサーチにより同定する。しかし、このせん断型モデルでは高次共 振振動数まで合わせ込むことが困難であった。次に、対象構造物が 柱・梁・床スラブのみで壁もブレースも無いことから通常の建物よ りも曲げ変形の寄与が大きいと考え、等価曲げせん断型モデル14) に モデル化し、1次〜 5次共振振動数の観測と解析の残差を最小にする 各層の質量・せん断岡性・曲げ剛性を同定した。この同定に際して は探索方法として遺伝的アルゴリズムとヒューリスティック法を組 み合わせたハイブリッドヒューリスティック探索 ${ }^{15)}$ （HHS）を用 いパラメタの増大による計算負荷の増加を防いだ。

\section{2. 対象構造物及び付加質量載荷実験の概要}

対象構造物は、京都大学宇治キャンパス構内に建設されている $1 \times 2$ スパンの 5 層実大鉄骨架構である。架構全体写真及び観測機器の 設置状況、錘載荷状況を図1に示す。観測機器としてサーボ型加速

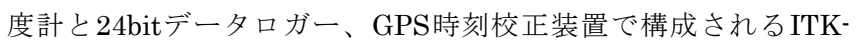
sensor ${ }^{16)}$ を用いて、各層の中央部にこれを設置、連続地震・常時微 動観測を行っている。さらに、錘載せ換え直後に毎回30分間ミツト ヨ製微動計SMAR-6A3Pを各層の南東隅及び南西隅、屋上中央部に 設置し、微動観測を行っている。このSMAR-6A3Pによる観測デー タは今回の研究では使用していないが、ITK-sensorの精度を確かめ るため、ITK-sensor とSMAR-6A3Pのフーリエスペクトルを比較し た（図2）。ごく低振動数域を除きよく一致していることがわかる。

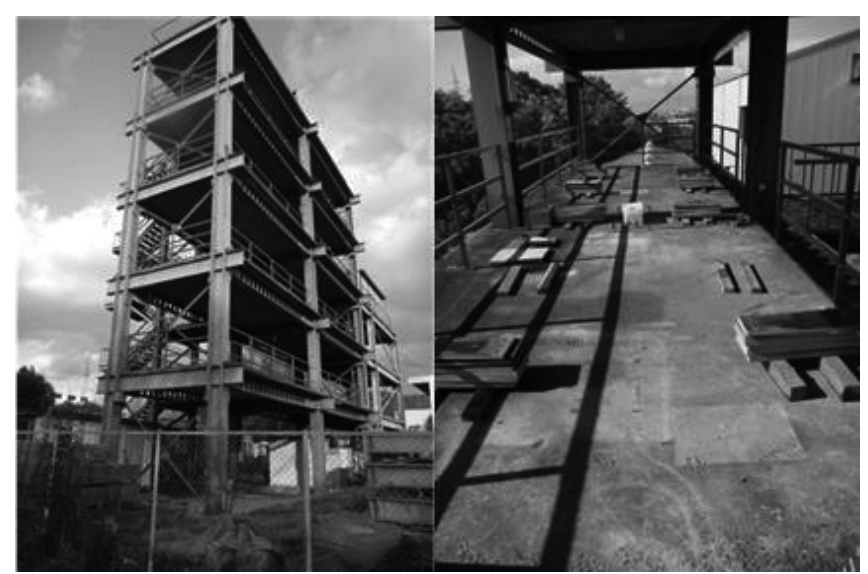

(a) 外観

(b) 観測機器及び鍾積載状

図 1 対象構造物

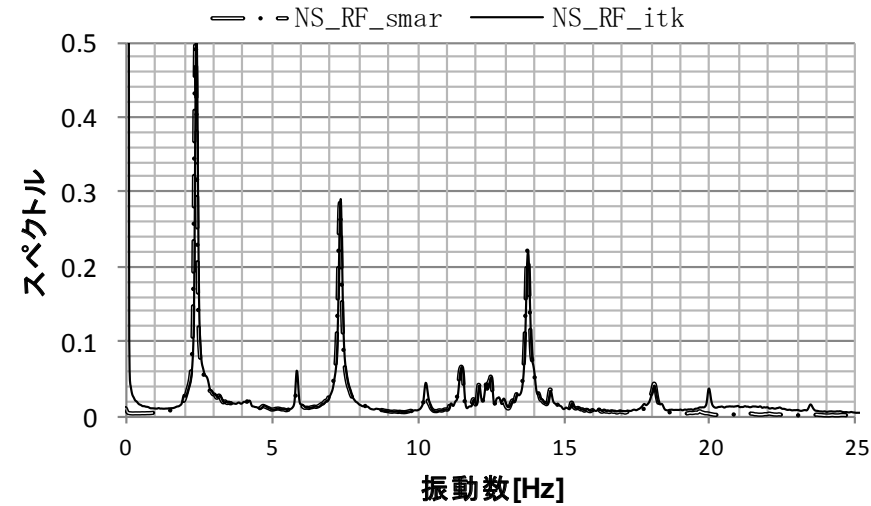

図 2 SMAR と ITKのフーリエスペクトルの比較

また、架構の平面図、立面図及び各寸法を図3に示す。さらに、 この寸法及び、柱・梁・スラブの断面寸法から式(1)により計算され た各層せん断剛性・曲げ剛性、及び質量を表1に示す。

$$
k=\frac{12 n E I}{h^{3}}, s=\frac{n t E A l^{2}}{h}
$$

$k$ : せん断剛性 $[\mathrm{kN} / \mathrm{mm}] 、 E$ : ヤング係数 $\left[\mathrm{N} / \mathrm{mm}^{2}\right]\left(=2.05 \times 10^{5}\right) 、$

$I:$ 柱1本の断面二次モーメント $\left[\mathrm{cm}^{4}\right] 、 n: 1$ 層の柱の本数

$h:$ 階高 $[\mathrm{m}] 、 s:$ 曲げ岡性 $[\mathrm{N} \cdot \mathrm{m} / \mathrm{rad}] 、 n t:$ 引張側の柱の本数 $A$ : 柱断面積 $\left[\mathrm{mm}^{2}\right] 、 l$ : 層の図心から柱断面図心までの距離 $[\mathrm{mm}]$

表1 断面寸法から求めた各物理パラメタ

\begin{tabular}{|c|c|c|c|}
\hline & 曲げ剛性 $[\mathrm{N} \cdot \mathrm{m} / \mathrm{rad}]$ & せん断剛性 $[\mathrm{kN} / \mathrm{mm}]$ & 質量[ton] \\
\hline 5 & $6.68 \times 10^{9}$ & 91.1 & 20.8 \\
\hline 4 & $6.62 \times 10^{9}$ & 88.7 & 21.8 \\
\hline 3 & $6.62 \times 10^{9}$ & 88.7 & 21.8 \\
\hline 2 & $9.97 \times 10^{9}$ & 132 & 23.1 \\
\hline 1 & $9.59 \times 10^{9}$ & 122 & 23.6 \\
\hline
\end{tabular}

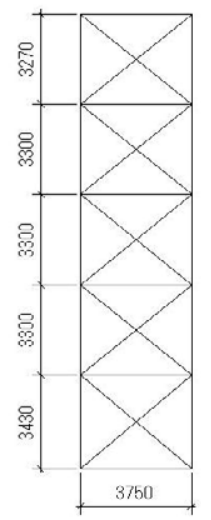

(a) 短辺方向立面図

\begin{tabular}{|c|c|}
\hline $\mathrm{Cl}$ & $\mathrm{Cl}$ \\
\hline $\mathrm{Cl}$ & $\mathrm{Cl}$ \\
\hline $\mathrm{Cl}$ & $\mathrm{Cl}$ \\
\hline $\mathrm{C} 2$ & C2. \\
\hline C2 & C2 \\
\hline 7500 & 7500 \\
\hline
\end{tabular}

(b) 長辺方向立面図

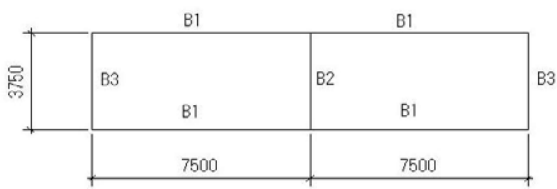

(c) 平面図

図 3 対象構造物の寸法 
なお本建物を対象とした既往研究例として、鈴木ら 17)によるもの があり、そこでは1層の質量は約30tonと推定されている。本研究に おける同定結果は全て短辺方向（NS方向）である。

さらに、前述した付加質量載荷実験の鍾載せ換えスケジュールを 表 2 に示す。建物の総重量の約 $1 \%$ 質量を付加すれば共振振動数の 変化を検知できるとされている12) が、本研究では、1枚 $30 \mathrm{~kg}$ の鉄板 100 枚、計3tonを用いて、付加質量は構造物の総重量の約 $2 \%$ と、 錘は、図1右に示寸通り、層に均等になるように配置した。

表2 錘載せ換えスケジュール

\begin{tabular}{|c|c|c|c|}
\hline $\begin{array}{c}\text { 錘乗せ換え } \\
\text { 完了日 }\end{array}$ & $\begin{array}{c}\text { 錘乗せ換え開始 } \\
\text { 時刻 }\end{array}$ & $\begin{array}{c}\text { 錘乗せ換え完了 } \\
\text { 時刻 }\end{array}$ & 錘載荷階 \\
\hline $10 / 30$ & $15: 00$ & $16: 00$ & $\mathrm{RF}$ \\
\hline $11 / 7$ & $14: 30$ & $15: 00$ & $\mathrm{RF} \rightarrow 5 \mathrm{~F}$ \\
\hline $11 / 16$ & $10: 30$ & $11: 00$ & $5 \mathrm{~F} \rightarrow 4 \mathrm{~F}$ \\
\hline $11 / 22$ & $10: 00$ & $10: 45$ & $4 \mathrm{~F} \rightarrow 3 \mathrm{~F}$ \\
\hline $11 / 30$ & $10: 30$ & $11: 17$ & $3 \mathrm{~F} \rightarrow 2 \mathrm{~F}$ \\
\hline $12 / 13$ & $13: 30$ & $13: 57$ & $2 \mathrm{~F} \rightarrow$ 無 \\
\hline
\end{tabular}

\section{3. 連続常時微動計測による共振振動数の推定}

連続常時微動計測によって得られた正時からの15分間の加速度波 形の観測記録を 40.96 秒の小区間を $50 \%$ オーバーラップさせて 42 区 間に切り出し、全層分全区間フーリエ変換する。さらに、1階と各 階とのフーリエスペクトル比を取り、アンサンブル平均值を求める。 その加速度波形・フーリエスペクトルの一例を図4、図5にそれぞれ 示す。共振振動数の推定の際には、共振振動数付近の振動数帯域に おいてスペクトル比が最も大きい点の振動数を取り、5層分の 42 区 間の平均 \pm 1 標準偏差内の平均值をその 1 時間における共振振動数と した。

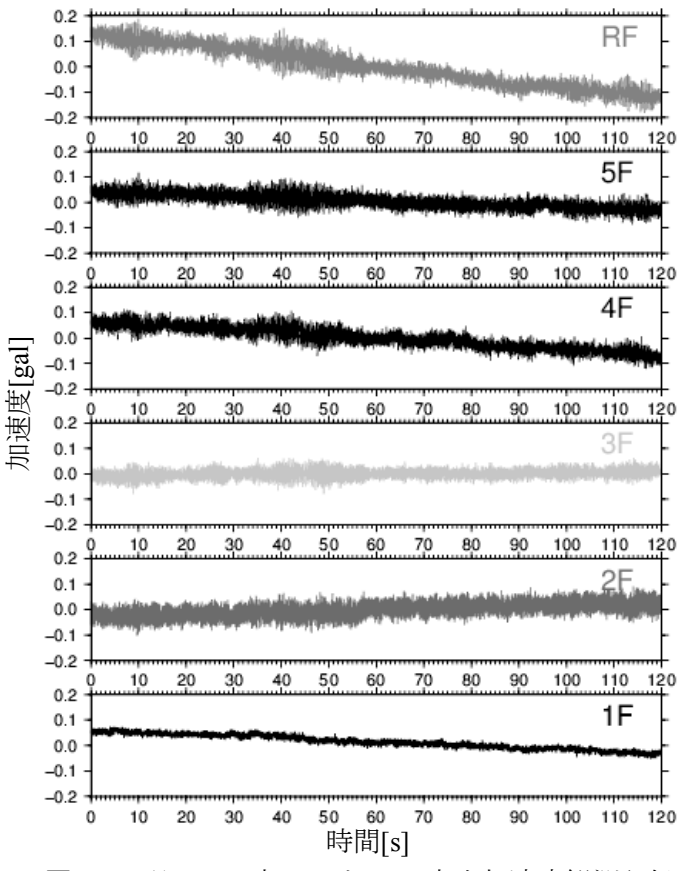

図4１0月8日15時におけるNS方向加速度観測記録

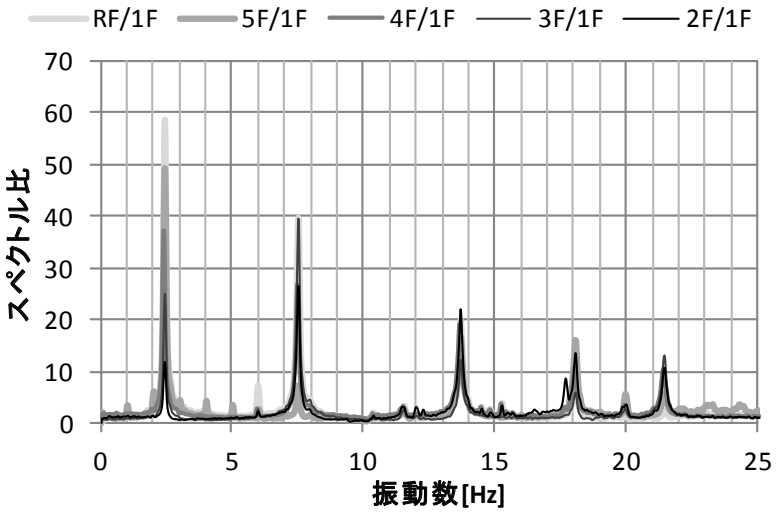

図5 10月8日15時におけるNS方向スペクトル比

ここで、各階に付加質量を載荷することによる各次共振振動数の 変動を図6に示す。各プロットは上述のように推定されたデータを 1 週間分（4階に錘を載荷した時のみ6日間）平均したものである。図 は1次から5次共振振動数に分けてプロットしている。グラフの縦軸 は各次の共振振動数 $(\mathrm{Hz})$ を示し、横軸は錘を載せている階を示して いるが、うち1は錘を載せていない状態、6は鍾を屋上階（5層目） に載せている状態を示す。また、横軸1でのロの振動数は付加質量 載荷実験終了後（12月中旬）の無載荷時データである。3次モード を除き実験前後による変動は小さい。実験後の3次共振振動数の増 加は、気温の低下による影響ではないかと推察されるが、常温レ心゙ ルの温度変化に対する高次固有振動数の変動の研究はほとんど報告 がなく、なぜ3次に大きく現れたのか原因究明には至っていない。
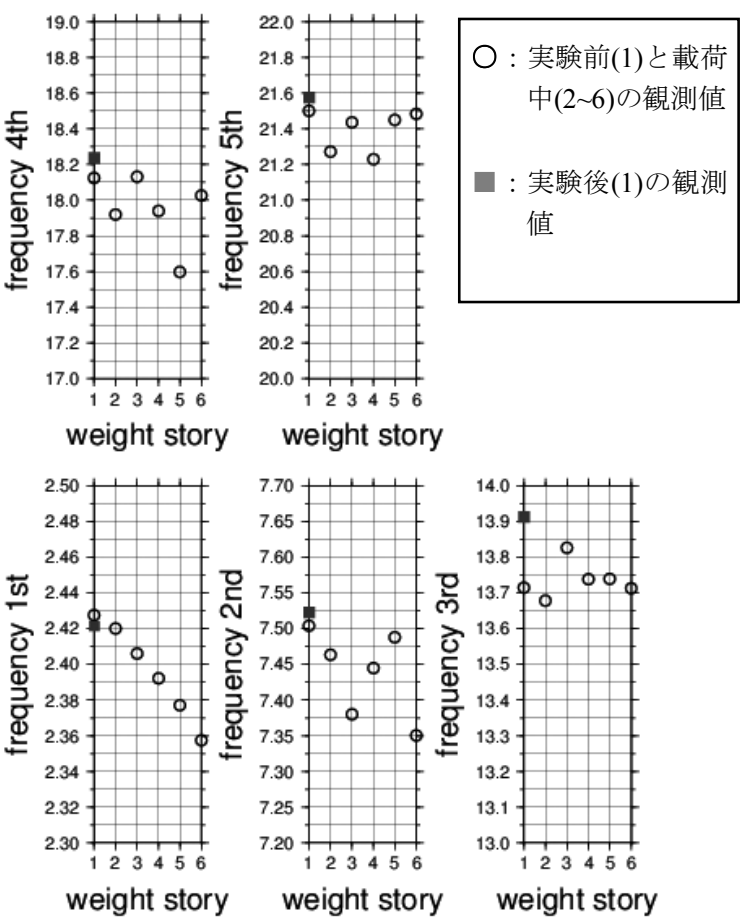

weight story

weight story

weight story

図6 付加質量載荷に伴う各次共振振動数の変動

4. せん断型モデルによる質量・剛性の同定

4.1 1次共振振動数に対する質量 ・ 剛性の同定

質量・せん断剛性の同定を行うにあたり、初めに簡便なモデル化 の適用性を検討するため、対象構造物を 5 自由度系せん断型モデル 
にモデル化した。同定の際の探索方法として、まず剛性は初期值の $\pm 50 \%$ の範囲内を $1 \%$ 刻みで、質量は $\pm 20 \%$ 範囲内を $0.5 \%$ 刻みで グリッドサーチを行い、通常時及び付加質量載荷時における1次共 振振動数 6 個をターゲットとして同定を行った。この際、剛性は各 層独立に探索し、質量は各層の初期值（表1）の相対比率は精度が よいと考え、基準值のみ探索すると6 個のパラメタを一意に決定す ることができる。その結果の各物理パラメタを表 $3 に 、$ 各次共振振 動数の観測記録と解析結果を図7に示寸。なお、図7におけるひし形 のプロットが解析結果であり、それ以外は図6と同一であるが、観 測記録と解析結果の差が大きいため、縦軸の目盛を変更している。

表3 せん断型モデルと1次共振振動数による剛性と質量の同定值

\begin{tabular}{|c|c|c|c|}
\hline & 曲げ剛性 $[\mathrm{N} \cdot \mathrm{m} / \mathrm{rad}]$ & せん断剛性[kN/mm] & 質量[ton] \\
\hline 5 & - & 45.9 & 20.4 \\
\hline 4 & - & 51.3 & 21.3 \\
\hline 3 & - & 51.3 & 21.3 \\
\hline 2 & - & 71.9 & 22.6 \\
\hline 1 & - & 61.9 & 23.1 \\
\hline
\end{tabular}

( - : 同定対象外)
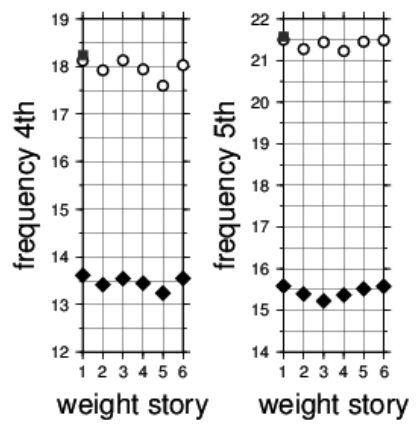

○：実験前(1) と載荷
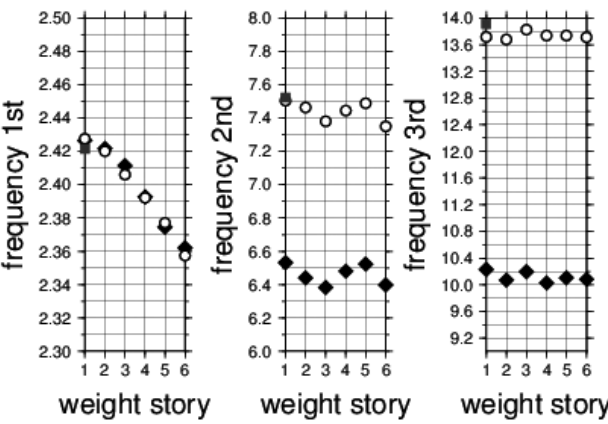

図7

せん断型モデルによる1次共振振動数同定時の付加質量載荷に 伴う各次共振振動数の変動

\subsection{2次共振振動数に対する質量・剛性の同定}

4.1節で得られた質量・剛性を初期值として、解析結果（表3のモ デル）の1次共振振動数及び1次のモード形状を固定したまま 2 次共 振振動数に合うような質量・剛性を同定する。その際に(2) (4)式18) を用いる。

$$
\begin{aligned}
K_{j} & =\left[\varphi_{j}\right]^{T}[K]\left[\varphi_{j}\right] \\
M_{j} & =\left[\varphi_{j}\right]^{T}[M]\left[\varphi_{j}\right] \\
\omega_{j} & =K_{j} / M_{j}
\end{aligned}
$$

ここで、 $\mathrm{j}:$ モード次数、 $\left[\varphi_{\mathrm{j}}\right] \mathrm{j}$ 次におけるモードパラメタ、 $\left[\varphi_{\mathrm{j}}\right] \mathrm{T}:\left[\varphi_{\mathrm{j}}\right]$ の 転置行列、 $\mathrm{K}_{\mathrm{j}}$ : 広義の剛性、 $\mathrm{M}_{\mathrm{j}}$ : 広義の質量、 $\omega_{\mathrm{j}} \mathrm{j}$ 次共振振動数、 $[\mathrm{K}]$ : 剛性行列、[M]:質量行列を表す。

1次共振振動数を固定するために、 $\mathrm{j}=1$ とし、 $\left[\varphi_{\mathrm{j}}\right]$ に次モードを代 入することで、 $\mathrm{K}_{1}$ を計算する。さらに、 $\mathrm{n}(1 \leqq \mathrm{n} \leqq 5)$ 層目の剛性を $\mathrm{\alpha}$ 倍 し、その他の剛性を $B$ 倍する。例えば $\mathrm{n}=1$ の時、剛性行列は(5)式の ように表わされる。

$$
K_{1}=\left[\varphi_{1}\right]^{T}\left(\begin{array}{ccccc}
\alpha k_{1}+\beta k_{2} & -\beta k_{2} & 0 & 0 & 0 \\
-\beta k_{2} & \beta k_{2}+\beta k_{3} & -\beta k_{3} & 0 & 0 \\
0 & -\beta k_{3} & \beta k_{3}+\beta k_{4} & -\beta k_{4} & 0 \\
0 & 0 & -\beta k_{4} & \beta k_{4}+\beta k_{5} & -\beta k_{5} \\
0 & 0 & 0 & -\beta k_{5} & \beta k_{5}
\end{array}\right)\left[\varphi_{1}\right]
$$

aが決まれば、 $\mathrm{K}_{1}$ は計算されているので、Bも一意に決まる。ここで、 $\alpha$ a.95 1.05の間で変化させ、観測記録の 2 次共振振動数に最も近 い時の $\alpha 、 B の$ 組み合わせを採用する。 $\alpha$ を0.95 1.05 と狭い区間にし ているのは、1次共振振動数を利用して第一次近似值を得ており、 その修正幅は小さいと考えられるからである。これを $\mathrm{n}=1 \sim 5$ で繰り 返し、さらに質量においても同様の作業を行う。(5)式と同様に、

$M_{1}=\left[\varphi_{1}\right]^{T}\left(\begin{array}{ccccc}\alpha m_{1}+\beta m_{2} & 0 & 0 & 0 & 0 \\ 0 & \beta m_{2}+\beta m_{3} & 0 & 0 & 0 \\ 0 & 0 & \beta m_{3}+\beta m_{4} & 0 & 0 \\ 0 & 0 & 0 & \beta m_{4}+\beta m_{5} & 0 \\ 0 & 0 & 0 & 0 & \beta m_{5}\end{array}\right)\left[\varphi_{1}\right]$

となり、同様に $\alpha$ を0.95 1.05の間で変化させ、観測記録の 2 次共振 振動数に最も近い時の $\mathrm{a} ， \boldsymbol{B}$ の組み合わせを採用する。これを $\mathrm{n}=1 \sim 5$ で繰り返す。この一連の作業を 2 次共振振動数の $\pm 0.1 \%$ 範囲にな るまで繰り返す。このようにして得られた各物理パラメタを表4に、 その時の付加質量載荷に伴う各次共振振動数の変化を図8 8 に示す。 図からデータで拘束された 1 次と 2 次の共振振動数はよく再現される ものの、拘束されていない高次モードは改善されていないことがわ かる。同様の解析を繰り返せば順次高次モードも同定可能であるが、 高次モードでは曲げ変形の影響が大きくなること、曲げ剛性を考慮 するとグリッドサーチでは効率が悪いことから、次節の等価曲げせ ん断モデルを用いたHHS法による同定を試みた。

なおここではスペースの関係で省略したが、観測によって得られ た1次 5 次共振振動数の全情報を用いてせん断モデルに適用し、5 章 と同様の探索手法により同定を試みたが、拘束条件によって同定結 果が大きく変動し、安定した解を導き出すことができなかった。

表4 せん断型モデルと2次共振振動数による剛性と質量の同定値

\begin{tabular}{|c|c|c|c|}
\hline & 曲げ岡性 $[\mathrm{N} \cdot \mathrm{m} / \mathrm{rad}]$ & せん断剛性 $[\mathrm{kN} / \mathrm{mm}]$ & 質量[ton] \\
\hline 5 & - & 54.9 & 22.2 \\
\hline 4 & - & 61.9 & 21.3 \\
\hline 3 & - & 49.7 & 20.5 \\
\hline 2 & - & 69.8 & 15.1 \\
\hline 1 & - & 59.0 & 16.1 \\
\hline
\end{tabular}

( - : 同定対象外 $)$ 

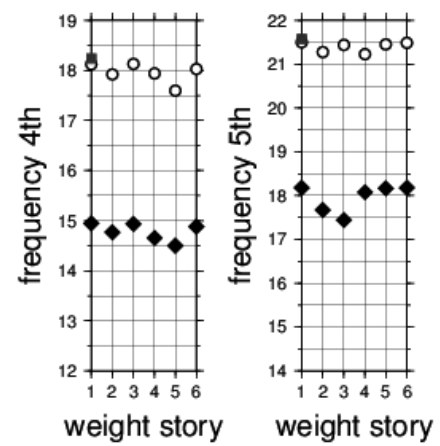

$\bigcirc$ : 実験前(1) と載荷 中(2 6)の観測值

口: 実験後 $(1)$ の観測 值

: 解析結果
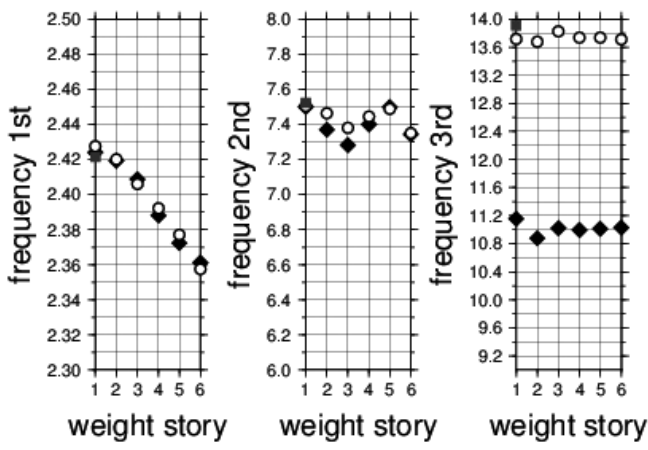

せん断型モデルによる 2 次共振振動数同定時の付加質量載荷に 伴う各次共振振動数の変動

\section{5. 等価曲げせん断型モデルによる質量・剛性の同定方法}

\section{1 等価曲げせん断型モデルによるモデル化}

まず、質量・せん断剛性・曲げ剛性の同定を行うにあたり、対象 構造物を 5 自由度系等価曲げせん断型モデルにモデル化する。非減 衰の固有方程式を次式に記述寸る。

$$
\left(-\omega^{2}\left[\begin{array}{cc}
M & 0 \\
0 & J
\end{array}\right]+\left[\begin{array}{cc}
K_{x x} & K_{x \theta} \\
K_{\theta x} & K_{\theta \theta}
\end{array}\right]\right)\left[\begin{array}{l}
x \\
\theta
\end{array}\right]=0
$$

$M$, ル $5 \times 5$ の質量マトリクス、回転慣性マトリクス、 $K_{x x}, K_{x \theta}, K_{\theta x}, K_{\theta \theta}$ は剛性マトリクス、 $\omega$ は固有円振動数で、剛性マトリクスは次式で 表わす。

$K_{x x}=\left[\begin{array}{cccc}k 1+k 2 & -k 2 & & \\ -k 2 & k 2+k 3 & \ddots & \\ & \ddots & \ddots & \\ & & & k 5\end{array}\right]$

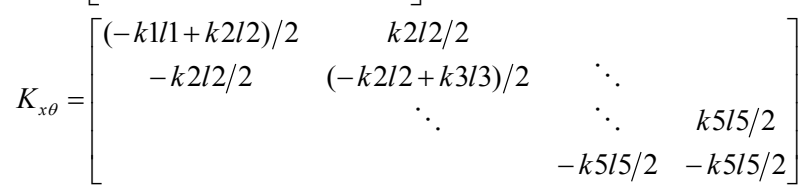

$$
K_{\theta x}=\left[\begin{array}{cccc}
(-k 1 l 1+k 2 l 2) / 2 & -k 2 l 2 / 2 & & \\
k 2 l 2 / 2 & (-k 2 l 2+k 3 l 3) / 2 & \ddots & \\
& \ddots & \ddots & -k 5 l 5 / 2 \\
& & k 5 l 5 / 2 & -k 5 l 5 / 2
\end{array}\right]
$$

$K_{\theta \theta}=\left[\begin{array}{cccc}\left(k 1 l l^{2}+k 2 l 2^{2}\right) / 3+s 1+s 2 & k 2 l 2^{2} / 6-s 2 & & \\ k 2 l 2^{2} / 6-s 2 & \left(k 2 l 2^{2}+k 3 l 3^{2}\right) / 3+s 2+s 3 & \ddots & \\ & \ddots & \ddots & k 5 l 5^{2} / 6-s 5 \\ & & k 5 l 5^{2} / 6-s 5 & k 5 l 5^{2} / 3+s 5\end{array}\right]$

さらに、(7)式は固有值解析を行う際に精度上の問題が生じるため、
5自由度系の全高を $H[\mathrm{~m}]$ として、

$$
\left(-\omega^{2}\left[\begin{array}{cc}
M & 0 \\
0 & J / H^{2}
\end{array}\right]+\left[\begin{array}{cc}
K_{x x} & K_{x \theta} / H \\
K_{\theta x} / H & K_{\theta \theta} / H^{2}
\end{array}\right]\right)\left[\begin{array}{c}
x \\
H \theta
\end{array}\right]=0
$$

とし、 $J / H^{2}=0$ と仮定する19)ことにより、(9)式は、

$$
\left(\omega^{2} M+\left[K_{x x}\right]-\left[K_{x \theta} / H\right]\left[K_{\theta \theta} / H^{2}\right]^{-1}\left[K_{\theta x} / H\right]\right)\{x\}=\{0\}
$$

と書ける。この(10)式に対して、QR法を用いて固有值解析を行う。 その際の同定方法を次節に示す。

\subsection{HHS法によるパラメタ同定}

ここでの同定スキームは基本的に 4 章と同じで、観測された共振 振動数と曲げせん断型モデルの非減衰固有振動数の差を最小化する ことである。解空間は 30 自由度、未知数は 15 自由度である。同定に 際しては、物理パラメタの探索方法として、遺伝的アルゴリズム (GA) とヒューリスティック法(SA)を組み合わせたハイブリッドヒュ ーリスティック探索15) (HHS)を用いる。このGAとSAの組み合わせ は、文献15),20) では、地盤モデルのS波速度分布を推定するために用 いられているが、構造物の物理パラメタの推定にも十分適用可能だ と考えられる。この方法はGAを基本としているが、焼きなまし法 と同様に、交叉における受理確率を世代の更新数の増加とともに低 下していく温度の関数として定義することで、大局的探索と局所的 探索の両方が可能となり、GAによる同定8) と比較して収束性・安定 性ともに高くなっている。さらに、進化戦略21)と比較して、ターゲ ットの残差值で優劣判定を行っているので収束判定ができるという 利点がある。

HHS法における目的関数を(11)式で表わし、重みwを付けて残差 质小化する重み付きHHS法によって物理パラメタを推定する。

$$
\Omega=\sum_{j=1,6} \sum_{i=1,5} w_{(i, j)} \frac{\left(f_{(i, j)}-f_{(i, j)}^{0}\right)^{2}}{\left(f_{(i, j)}^{0}\right)^{2}}
$$

$f_{(i, j)}$ : 観測記録から得たj階に鍾を載荷した時の $i$ 次共振振動数 $f_{(i, j)}^{0}$ : 解析結果から得た $j$ 階に鍾を載荷した時の $i$ 次共振振動数 $w_{(i, j)}: j$ 階に鍾を載荷した時のi次共振振動数に対する重み。 基本 1 とし、必要に応じて変化させる。 $j=1$ は鍾なし。

その際の制約条件をここでは次のように定めた。

\section{I. $\mathrm{M} 5=\min (\mathrm{M} 1 \sim \mathrm{M} 5)(\mathrm{M} 1 \sim \mathrm{M} 5$ :各層の質量 $)$}

II. $\quad \max (\mathrm{M} 1 \sim \mathrm{M} 5) / \min (\mathrm{M} 1 \sim \mathrm{M} 5)<1.3$

III. $\max (\mathrm{K} 1 \sim \mathrm{K} 5) / \min (\mathrm{K} 1 \sim \mathrm{K} 5)<3(\mathrm{~K} 1 \sim \mathrm{K} 5$ : 各層のせん断岡性)

IV. $\quad \max (\mathrm{S} 1 \sim \mathrm{S} 5) / \min (\mathrm{S} 1 \sim \mathrm{S} 5)<5(\mathrm{~S} 1 \sim \mathrm{S} 5$ : 各層の曲げ剛性)

V. $1 / 1.3<\mathrm{Mi} / \overline{\mathrm{M}}<<1.3(\mathrm{i}=1 \sim 5, \overline{\mathrm{Mi}}$ : 各層の質量の初期值 $)$

VI. $1 / 2<\mathrm{Ki} / \overline{\mathrm{Ki}}<2(\mathrm{i}=1 \sim 5, \overline{\mathrm{Ki}}$ :各層のせん断剛性の初期值)

VII. $1 / 3<\mathrm{Si} / \overline{\mathrm{Si}}<3(\mathrm{i}=1 \sim 5, \overline{\mathrm{Si}}$ :各層の曲げ剛性の初期值)

ここで、 $\max (-), \min (-)$ はそれぞれ( )内のパラメタの最大值及び最小 值であり、V. VII.での初期值は、4章と同様に表1の結果である。

I.に関しては床スラブ・鉄骨梁の断面寸法から明らかであったの 
で5層目の質量が最小と設定した。II.に関しては、スラブ・鉄骨梁 の断面寸法及び単位体積重量を考慮して、質量の最大值と最小值の 比は1.3を超えることは無いと判断した。また、表1や4章の結果か ら、質量は初期值からのずれが小さく、せん断剛性は初期值からの ずれが大きいと仮定し、さらに、曲げ岡性のずれは予測しにくいこ とから、V.〜VII.のような制約条件を設けた。III.とIV.に関しては、 非現実的な探索範囲とならないように、せん断剛性及び曲げ岡性の 最大值と最小值の比をそれぞれ 3,5 とした。

HHS法の遺伝的アルゴリズムにおける 1 世代ごとの個体数を 5000 、 世代数を 1000 、初期温度を $100^{\circ}$ とし、温度低下率を $\exp \left(-\mathrm{k}^{0.5}\right)$ と設 定、 $\mathrm{k}$ の初期值は 0 で50世代ごとに+1した。また、遺伝的アルゴリズ ムの交叉や突然変異の過程において、ある物理パラメタがV. VII.の 制約条件の範囲外の值となった場合には、その個体を除外するため、 初期個体数を大きくしている。除外される個体数は 1 世代に 500 個体 程度であり、世代ごとに新たな5000個体が生み出されるので問題な いと考えられる。HHSのフローチャートを図 9 に示す。各残差計算 の際に、(10)式を用いて、モデルの共振振動数を計算した。

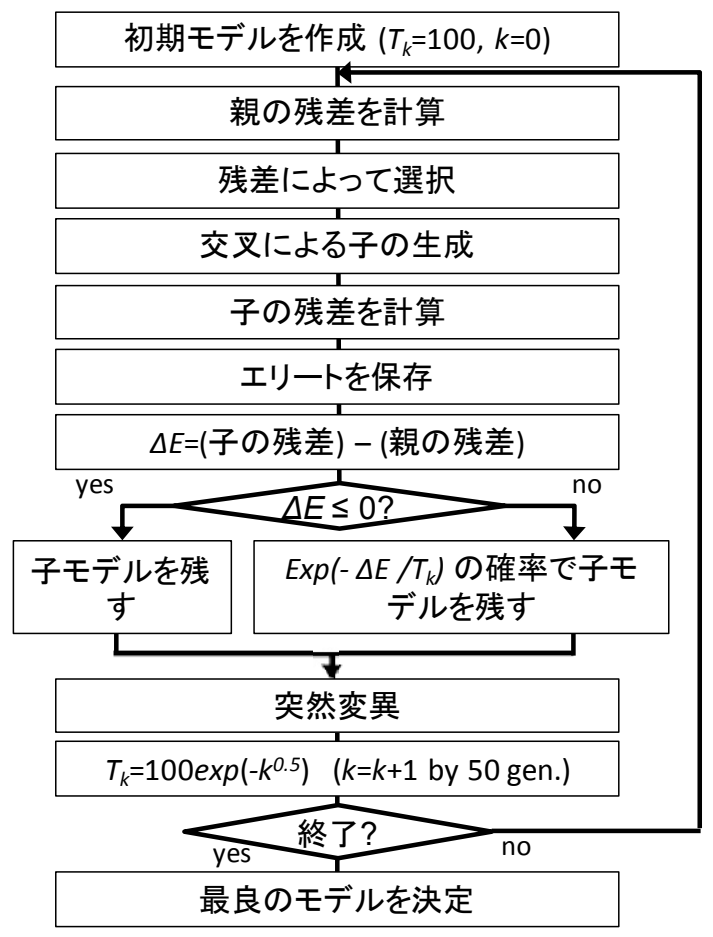

図9ＨHSフローチャート

\section{3 物理パラメタ同定結果}

5.1 節のモデル化及び5.2節の探索法を用いて、実際に質量・せん 断剛性・曲げ剛性を同定した。その際、付加質量を載荷していない 通常時の3次共振振動数において、載荷実験前後での共振振動数の 変化は大きく、どちらを無負荷時のデータとするかを決める必要が ある。付加質量載荷実験は、表 2 のおり主として11月に行われた ことから、実験後の 12 月中旬の方が季節変化の影響が少ないと考え、 その3次振動数を残差計算時の無載荷時データとして扱った。さら に、実験の付加質量載荷が $\mathrm{RF} \rightarrow 5 \mathrm{~F} \rightarrow 4 \mathrm{~F} \rightarrow 3 \mathrm{~F} \rightarrow 2 \mathrm{~F}$ と行われたこ とから付加質量がRFの記録は季節変化の影響が大きく、逆に $2 \mathrm{~F} の$ 記録は季節変化の影響が小さいと考えられる。それらのことを考慮
し、(11)式に設定した通り残差は共振振動数の 2 乗に比例させてい ることから、今回は3次共振振動数に対しては(12)式に示寸重みを設 定した。

$$
\begin{aligned}
& w_{(3,1)}=1.0, \quad w_{(3,2)}=0.81, \quad w_{(3,3)}=0.49, \\
& w_{(3,4)}=0.25, \quad w_{(3,5)}=0.09, \quad w_{(3,6)}=0.01
\end{aligned}
$$

また、3階に錘を載荷した時の5次共振振動数においては、そのスペ クトルピークがあまり明瞭でなく、読み取り值の安定性が低かった ため、残差計算の対象外とし、(13)式の重みを設定した。

$$
w_{(5,3)}=0.0
$$

ここで、実際にプログラムをランダムに生成した異なる初期世代 を用いて8回実行して収斂の計算を行った。図10は、横軸が世代数、 縦軸が最良個体の残差である。ここまでに示した拘束条件及び重み 設定によって、各試行における残差の差は非常に小さく、よく収斂 していることが分かる。さらに、試行毎に同定された各物理パラメ 夕を図11に示す。図10から、最も残差が小さく同定された物理パラ メタを最適なモデルと考え（5回目）、その結果を表5に示す。さら に表6には推定のばらつきを表す指標として8回の試行結果の平均土 標準偏差の值を示した。対象が共振振動数であるので当然のことで あるが、大きな剛性となっている最適モデルは大きな質量となって いる。付加質量載荷によって変動する、観測記録と同定されたモデ ルによる解析結果の共振振動数の比較を図 12 に示寸。3次の屋上載 荷時の共振振動数の重みw(3,6) は0.01としたので条件としてほとんど 参照されていないはずだが、結果は再現されている。

図13にはその同定されたモデルでの通常時(付加質量を載荷してい ない時)のモード性状を示す。ここで○とロはこれまで同様実験前・ 後を表している。共振振動数では3次モードを除いてわずかな変動 しか見られなかったが、このモード振幅には少ないものの実験前後 で差異が見られ、その変動幅と同程度のずれで観測モード振幅を （3次の3階、5次の屋上階を除き）説明できていることから、同定 された物理パラメタが妥当であることを支持しているものと考えら れる。なおこの図で3次は実験後のそれと比較すべきものである。

ここで、探索範囲を質量は初期值（表1参照）の1/1.3 1.3倍、せ 儿断剛性は初期值の1/2 2倍、曲げ岡性は初期值の $1 / 3 \sim 3$ 倍の範囲内

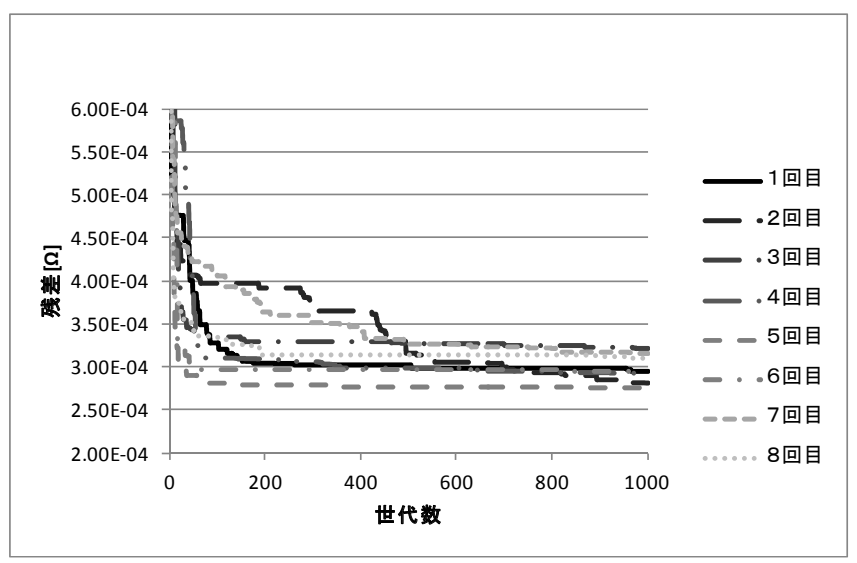

図10 試行毎の残差の収斂の様子 


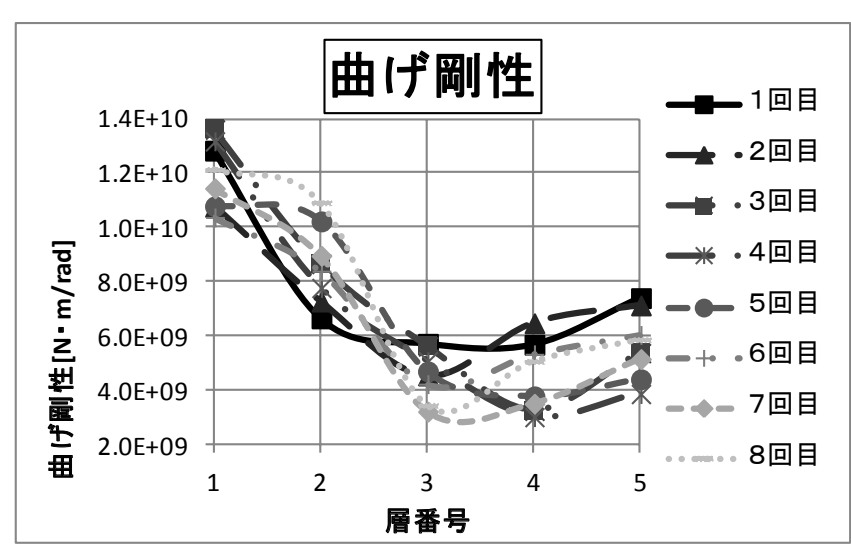

(a) 曲げ剛性

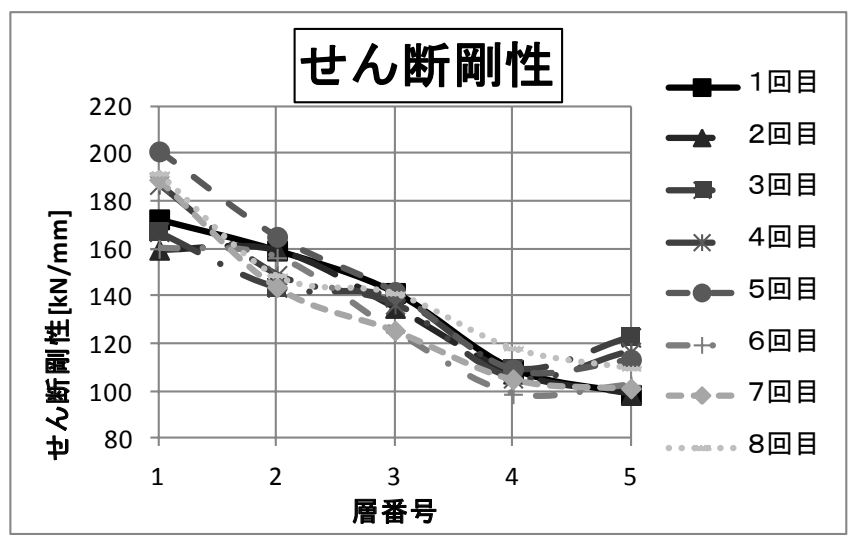

(b) せん断剛性

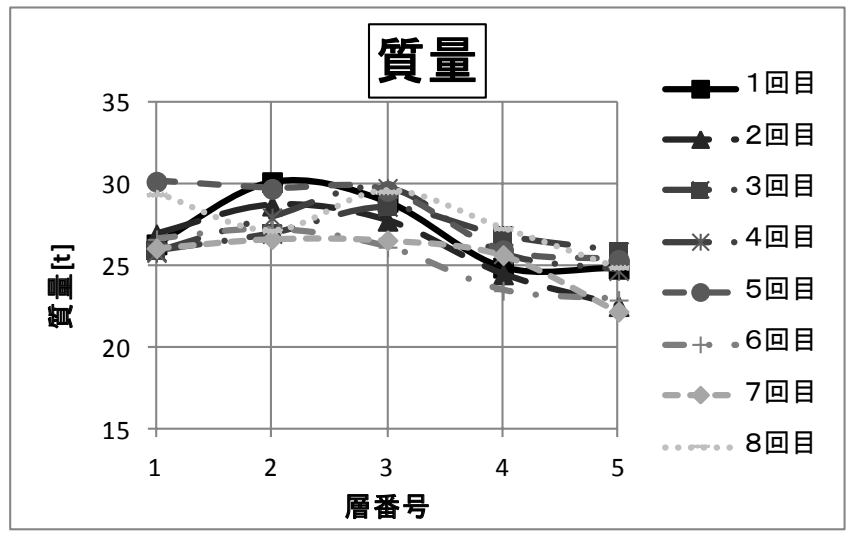

(c) 質量

図11 試行毎に同定された物理パラメタのばらつき

表5 等価曲げせん断型モデルで同定された最適物理パラメタ

\begin{tabular}{|c|c|c|c|}
\hline & 曲げ岡性 $[\mathrm{N} \cdot \mathrm{m} / \mathrm{rad}]$ & せん断岡性 $[\mathrm{kN} / \mathrm{mm}]$ & 質量[ton] \\
\hline 5 & $4.43 \times 10^{9}$ & 113 & 25.4 \\
\hline 4 & $3.80 \times 10^{9}$ & 109 & 26.0 \\
\hline 3 & $4.71 \times 10^{9}$ & 142 & 29.6 \\
\hline 2 & $10.2 \times 10^{9}$ & 165 & 29.7 \\
\hline 1 & $10.8 \times 10^{9}$ & 201 & 30.2 \\
\hline
\end{tabular}

として、各パラメタにおいて 10 点の試行值をとり、グリッドサーチ を単純に行う場合、計算回数は、 $10^{5} \times 10^{5} \times 10^{5}=10^{15}$ 回となる。しか
し、HHS法では、個体数が 5000 、世代数 1000 、交叉確率、突然変 異確率はともに 0.15 とており、これを 8 回行ったので、計算回数 は、 $8 \times((5000+5000 \times 0.15+5000 \times 0.15) \times 1000)=5.2 \times 10^{7}$ 回となり、 総計算数を $1.9 \times 10^{-7}$ 倍にまで減らすことが可能であった。

表6 同定された物理パラメタの8試行の平均士標準偏差

\begin{tabular}{|c|c|c|c|}
\hline & 曲げ岡性[N·m/rad] & せん断岡性 $[\mathrm{kN} / \mathrm{mm}]$ & 質量[ton] \\
\hline 5 & $(5.67 \pm 1.14) \times 10^{9}$ & $108 \pm 8.51$ & $24.2 \pm 1.31$ \\
\hline 4 & $(4.53 \pm 1.20) \times 10^{9}$ & $108 \pm 5.11$ & $25.6 \pm 1.16$ \\
\hline 3 & $(4.59 \pm 0.85) \times 10^{9}$ & $136 \pm 6.48$ & $28.4 \pm 1.31$ \\
\hline 2 & $(8.62 \pm 1.34) \times 10^{9}$ & $153 \pm 7.43$ & $28.1 \pm 1.23$ \\
\hline 1 & $(11.89 \pm 1.14) \times 10^{9}$ & $178 \pm 14.7$ & $27.2 \pm 1.56$ \\
\hline
\end{tabular}

\section{6. 結論}

実大鉄骨架構において連続常時微動観測を行い、付加質量載荷実 験による共振振動数の変化から物理パラメタ（剛性と質量）を同定 した。その結果以下の知見が得られた。

（1）実大架構の各層において比較的安価な加速度地震計を設置し、 連続常時微動観測を行うことで、各次の共振振動数を精度よく 推定することができた。また、3次共振振動数においては実験 前後での共振振動数変化は大きかったものの、その3次も含め た 1 次〜 5次の全対象共振振動数において総重量の $2 \%$ の付加質 量載荷による有意な変化が検出された。

（2）対象構造物を 1 本棒せん断型モデルにモデル化した場合、1次 及び2次共振振動数に合わせ込むことは可能であったが、高次 共振振動数においては観測記録と解析結果の差は大きく、等価 曲げせん断型モデルへのモデル化の必要性が示された。これは、 対象構造物が柱・梁・床スラブのみでできているスケルトン構 造であることに起因すると推定される。

（3）対象構造物を等価曲げせん断型モデルにモデル化する際に、回 転慣性 $=0$ と仮定して縮約することにより、パラメタの増大を 防いだ。このモデルによる同定段階において、対象構造物の実 測情報から適切な拘束条件を設けて、HHS法を使用すること により、観測記録を説明できる物理パラメタを精度よく同定す ることができた。モード性状を拘束条件として用いていないの にもかかわらず観測記録と解析結果のモード性状もよく再現で きており、1層目の剛性が相対的に大きく、3 5層目の剛性が 相対的小さいという同定結果の傾向も初期生成モデルの如何に かかわらず普遍的にみられた。

なお、曲げせん断型振動モデルの同定結果（表5）を正解と考え てせん断型モデルの同定結果（表3、表4）と比較してみると、質量 推定值は1次の同定結果（表3）の方が精度よく、剛性推定值もその 高さ方向分布は1次の同定結果の方が妥当なので、2次にも適合させ たことによって必ずしも解が改善されたとは言えない結果となった。

今回は短辺方向のみをターゲットに同定を行ったが、今後は長辺 方向についても、長辺方向単独および2方向同時で同定を行うとと もに、減衰も考慮した同定も行い、多角的に同定の精度について検 討していきたい。 


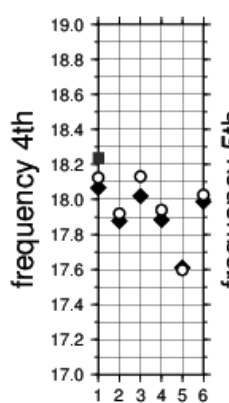

weight story

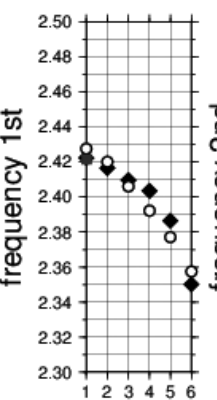

weight story

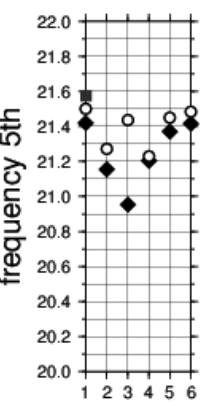

weight story

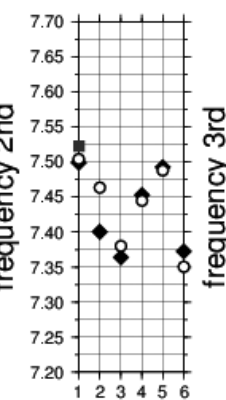

weight story
○: 実験前(1) と載荷 中 $(2 \sim 6)$ の観測值

口: 実験後 $(1)$ の観測 值

• : 解析結果
等価曲げせん断型モデルによる同定時の付加質量載荷に伴う

各次共振振動数の変動
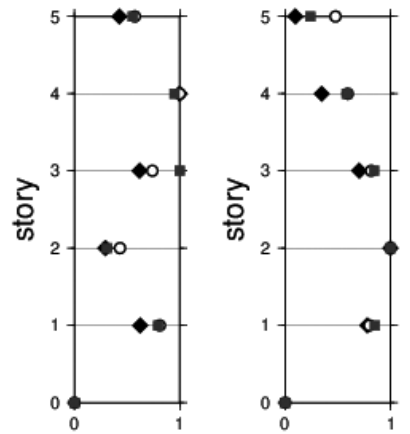

○ : 実験前の観測值

mode 4 th

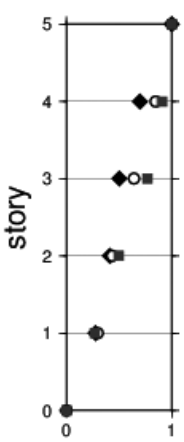

mode 5th
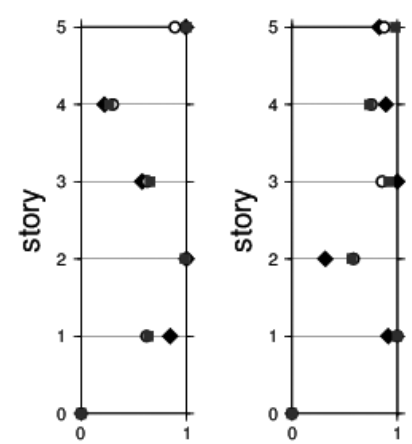

図13 同定した等価曲げせん断型モデルによる通常時（付加質量を 載荷していない時）における各次のモード性状と観測值の比較 謝辞

本研究の実施にあたって、川瀬・松島研究室メンバーと山崎友也
氏をはじめとする防災研究所技術職員の皆様には付加質量載荷実験 にあたって多大なご協力を頂きました。ここに、深く感謝の意を示 します。また、地震防災研究部門・耐震機構研究分野の中島研究室 の倉田真宏助教には、今回使用した実大鉄骨架構の寸法図面を提供 していただきました。心より御礼申し上げます。本研究の一部は日 本学術振興会の科学研究費補助金 (基盤研究(C)22560560)の助成を 受けて行いました。

\section{参考文献}

1） 中村充・安井譲 : 微動測定に基づく地震被災鉄骨建物の層損傷評価，日本 建築学会構造系論文集, No.517, pp.61-68, 1999.3 .

2）池田芳樹：モード情報との整合性を考慮したせん断振動型建物の層剛性 の同定,日本建築学会構造系論文集, No.646, pp.2237-2243, 2009.12.

3）前田朋宏・吉富信太・竹脇出：限定された地震観測記録とARXモデルを 用いた建物の剛性・減衰同定法，日本建築学会構造系論文集，No.666, pp.1415-1423, 2011.8.

4）吉元怜毅・三田彰 : 多入力多出力モデルに基づく建築構造パラメタのオ ンライン同定, 日本建築学会構造系論文集, No.574, pp.39-44, 2003.12.

5）濱本卓司・大浴佳治・三好敏晴：アクティブ同定手法を用いた多層建築 物の損傷検出, 日本建築学会構造系論文集, No.539, pp.51-56, 2001.1.

6）濱本卓司・森田高市・勅使河原正臣：複数モードの固有振動数変化を用 いた多層建築物の層損傷検出, 日本建築学会構造系論文集, No.560, pp.93-100, 2002.10.

7）濱本卓司・森田高市・相馬澄子：逐次最小二乗法による多層建築物の地 震損傷追跡，日本建築学会構造系論文集, No.603,pp.39-46, 2006.5.

8）濱本卓司・井上了太 : 並列モデル同定を用いた多層建築物の部材損傷検 出, 日本建築学会構造系論文集, No.655, pp.1661-1670, 2010.9 .

9) Saito, T. $\cdot$ Mase, S. - Morita, K.: A Probabilistic Approach to Structural Damage Estimation, Structural Control and Health Monitoring, 12, pp.283-299, 2005.

10）池田芳樹：刺激関数を用いた線形計画法に基づく建物の質量同定，日本 建築学会構造系論文集, No.627, pp.749-756, 2008.5

11）古川忠稔: 線形多自由度系の物理パラメターの直接推定，日本建築学会構 造系論文集, No.640, pp.1113-1119, 2009.6.

12）森洋人・川瀬博：確定付加質量がもたらす共振振動数の変動に基づく $\mathrm{RC}$ 造建物の実質量と実剛性の同時同定，日本建築学会構造系論文集，No.559, pp.93-100, 2002.9.

13）川瀬博・森洋人・包那仁満都拉 : 質量変化に伴う振動数変化に基づいた 微小振幅時の免震層の剛性推定，日本建築学会構造系論文集，No.590, pp.37-44, 2005.4 .

14) Wada, A. • HUANG, Y.H. : Preliminary Seismic Design of Damage Tolerant Tall Building Structures, A New Direction in Seismic Design, Tokyo, 1995. 10

15）山中浩明：ハイブリッドヒューリスティック探索による位相速度の逆解 析, 物理探査, 第60巻, 第3号, 265-275, 2007.

16）鹰野澄・池田泰久：建物用IT強震計による建築物の地震時応答解析：構 造物ヘルスモニタリングへの応用に向けて, 日本地球惑星科学連合, S150P007, 2009.5.

17）鈴木祥之・山本雅史：実大構造物の地震応答加振システムに関する研究, 日本建築学会構造系論文集, No.514, pp.105-110, 1998.12 .

18）田治見宏:建築振動学, コロナ社, 1965 .

19）大崎順彦:振動理論，彰国社,1980.

20）長嶋史明・川瀬博・松島信一・早川崇・佐藤智美 : 地震動H/Vスペクトル 比を用いた拡散波動場理論に基づく地盤構造推定，日本建築学会大会学術 講演梗概集, Vol.B2, pp.211-212, 2013.9 .

21）鹿嶋俊英・北川良和： 強震記録に基づく進化戦略手法による建物の振 動特性評価, 日本建築学会構造系論文集, 第602号, pp.145-152, w2006.4. 